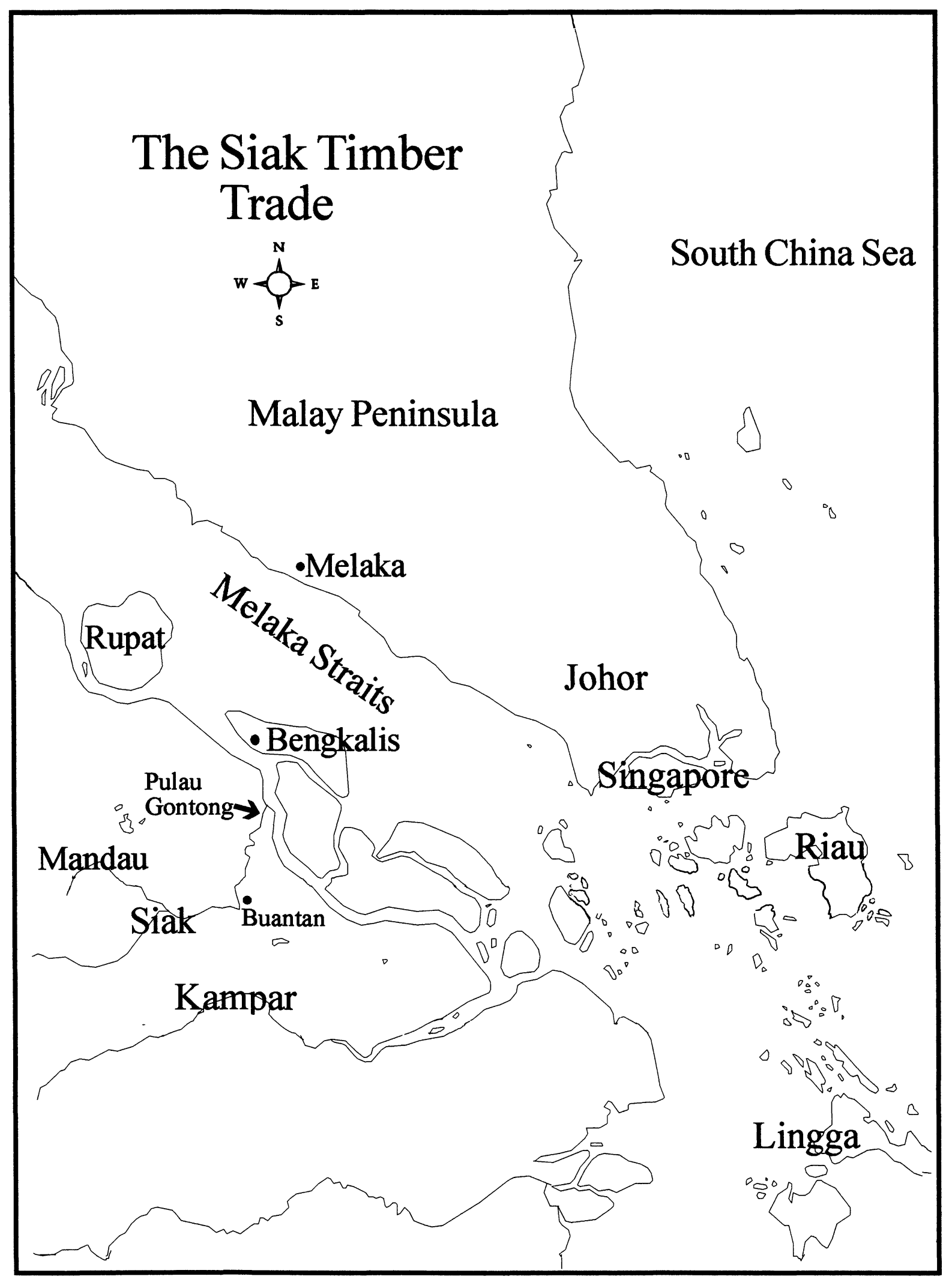




\section{THE TIMBER TRADE IN PRE-MODERN SIAK'}

Timothy P. Barnard

Situated in a region of seemingly endless lowland rain- and mangrove forest in eastern Sumatra, the Siak river is the deepest in the Malay archipelago and an important conduit for trade in the region. Before European colonial rule encompassed much of Southeast Asia during the nineteenth century, the Siak river was home to a number of small villages that acted as stapling posts for the collection and transfer of a variety of trade products, ranging from camphor and bezoar stones to tin and gold. These communities were also exporters of timber, for which Siak was well-known throughout the Straits of Melaka and as far away as Java.

Wood from eastern Sumatra was exported to other ports in the region, where it was used for construction and ship repairs, while a ship-building industry had been present along the Siak river for centuries. As mentioned in the best-known study of sixteenth-century Portuguese Melaka, The Suma Oriental of Tome Pires, a king of Siak "has many paraos, and they are made in his country, because of the amount of wood there." 2 The importance of Siak timber trade was enhanced by the nineteenth century as other regions of Southeast Asia, particularly those with easily accessible teak forests, became deforested. ${ }^{3}$ When supplies became low in Java, Siak continued to be "covered with fine and durable timber for ships and houses, ... [that], as far as I know, is not

\footnotetext{
${ }^{1}$ This paper was originally presented at the $49^{\text {th }}$ Annual Association for Asian Studies Conference, Chicago, 1997.

2 Tome Pires, The Suma Oriental of Tome Pires, vol. I, (London: Hakluyt Society, 1944), p. 150.

${ }^{3}$ Nancy Lee Peluso, Rich Forests, Poor People: Resource Control and Resistance on Java (Berkeley: University of California Press, 1992), pp. 27-28, 37; Luc Nagtegaal, Riding the Dutch Tiger: The Dutch East Indies Company and the Northeast Coast of Java, 1680-1743 (Leiden: KITLV, 1996), pp. 133-135; 193-198; Freek Columbijn, "Van dik Hout en Magere Verdiensten. Houtkap op Sumatra (1600-1942)," Spiegel Historiael 32 (1997): 435.
} 
88 Timothy P. Barnard

found in the Malay peninsula south of Pegu and Siam."4 One traveler to the region described the qualities of Siak timber as so "firm and durable, that ships of it would last forty or fifty years; whereas those that came from Europe are, generally speaking, worn out in twelve or thirteen." 5 Such a highly desired product does appear, albeit sparingly, in recorded accounts of Siak prior to colonial rule.

European reports about Siak timber often were rudimentary, usually only listing the amount of wood obtained and its size. In a report from 1763, it is stated that the thirty-three trees harvested ranged from sixty-three to eighty-five feet in height and were fourteen to twenty-four "palms" in width at the base and ten to eighteen "palms" in width at the top. The harvest usually occurred between June and October, the dry season in eastern Sumatra, when access would have been easiest. ${ }^{6}$

Remarks like these enumerating the size and number of trees harvested represent much of the daily interaction between the VOC (United East India Company) and Siak. In the example mentioned above, the timber is listed along with other items flowing from the port of Bengkalis to Melaka. Timber was simply another aspect of this trade. ${ }^{7}$ Since such traffic was common, the type of tree is rarely mentioned. A glimpse into the industry, briefly illuminating the various species of trees harvested and their uses, was provided in 1823 when an English envoy, John Anderson, had dinner with a Siak noble. During the meal it was mentioned that Siak forests could supply Penang and Singapore with up to sixteen different types of useful timber. ${ }^{8}$

${ }^{4}$ ARA 2.10.01, 3073: Ministrie van Kolonien, "Afschrift van een memorie in het Engels betreffende Malakka en verschillende Sumatranse gewesten (c. 1819)," p. 5.

5 Commodore Roggewein, "An Account of Commodore Roggewein's Expedition" in John Harris, ed., Complete Collection of Voyages and Travels, vol. I (London: n.p., 1744), p. 298; Jan Parmentier, "The Private East India Ventures from Ostend: The Maritime and Commercial Aspects," International Journal of Maritime History 5, 2 (December 1993): 78-79.

6 The dimensions of the Siak timber would have made it ideal for use as masts on some of the VOC's largest ships. Peluso, Rich Forests, Poor People, p. 37. For more information on the harvest and size of the trees in Siak, see VOC 2468 (Second Part): Dagh Register of Malacca, f. 176-179, 298-301; VOC 2502: Malacca to Batavia, September 27, 1740, f. 45; Dagh Register of Malacca, f. 259-261; VOC 2535: Dagh Register of Malacca, f. 279-283, 545-548; VOC 2630: Memorie of Gov. Rogier de Laver, f. 44; VOC 3153: Malacca Resolutions, October 15, 1764, f. 302-303.

${ }^{7}$ For other examples see VOC 2675: Malacca to Batavia, February 23, 1746, f. 24: Malacca to Batavia, September 6, 1746, f. 464.

${ }^{8}$ In 1833 a resident of Palembang mentioned 568 different tree species, while in 1874374 separate species were reported. Although few of these species would have been used for the timber trade, it was the diversity of the commercial Sumatran forests that amazed Dutch administrators who had previously worked in the teak forests of Java. F. H. Endert, "Silvicultural Notes on a Trip through Atjeh, East-Coast of Sumatra, Tapanoeli, and West-Coast of Sumatra," Tectona 18 (1925): 110-111; Columbijn, "Houtkap op Sumatra," p. 432; John Anderson, Mission to the East Coast of Sumatra in 1823 (Kuala Lumpur: Oxford University Press, 1971), p. 349; William Marsden, The History of Sumatra (Singapore: Oxford University Press, 1986), pp. 160-163. 
Local Name

Arang, Komodan

Daru Daru

Giam ${ }^{10}$

Koras, Koras Kese

Kulim

Medang ${ }^{11}$

Merbau

Perapo

Russa

Serapat
Commercial Timber used in Siak, c. $1823^{9}$

Latin Name

Diospyros spp.

Urandra spp.

Inocarpus edulis

Psychotria malayana

Scorodocarpus borneensis

Family: Lauraceae

Intsia spp.

Beilschmiedia malaccensis

Polyalthia spp.

Cratoxylon ligustrinum
Use

Ships' Knees, Furniture, Sword

Handles

Masts and Chests

Ships' Planks

Ship Timbers

Planks

Ship and House Planks

Furniture, Ship and House Planks

House Planks

Ship Planks

Ships' Masts

While a list of these species is interesting in that it provides data about the premodern Siak timber industry, additional sources help clarify relationships between parties involved in the trade. The information in European travelers' tales and the Dutch archives occasionally provides insight into the competition over access to land and trees, which Peluso has termed "forest politics."12 As was true in Java, the VOC and the British East India Company found it most convenient to focus on one supplier for the timber from eastern Sumatra. When Johor ostensibly controlled Siak in the sixteenth and seventeenth centuries, the VOC approached its officials requesting access, often overlooking the usufruct rights of the inhabitants of different parts of the Siak forest. The process usually began when officials in Melaka sent a ship to Bengkalis, the major trading center on the eastern Sumatran coast, where a Johorese representative, the syahbandar, oversaw regional trade but had little to do with the collection of forest and sea produce. Once the Dutch received permission from the syahbandar of Bengkalis, usually just a formality, their vessels then could proceed to locations in the region where the timber could be harvested. ${ }^{13}$ Although trees were

\footnotetext{
${ }^{9}$ Anderson, Mission to the East Coast of Sumatra in 1823, p. 349. For information on all the species listed in the table see I. H. Burkill, Dictionary of Economic Products of the Malay Peninsula, vol. II (London:

Government of the Straits Settlements and Federated Malay States, 1935); and R. J. Wilkinson, A MalayEnglish Dictionary (London: Macmillan, 1959).

${ }^{10} \mathrm{Giam}$ is the Malay term for otaheite chestnut. While common in Java, it was not believed to have been introduced to the Malay peninsula or Sumatra until 1876. Its hardness, similar to that of teak, would have made it a valuable product in any shipyard on Sumatra. Its presence in Siak in the early nineteenth century suggests either the presence of substantial trade networks established to obtain the valuable hardwood - these networks would have been greater than previously thought—or, alternately, they suggest active attempts to transplant these hardwood trees to commercial forests in Sumatra. Burkill, Dictionary of Economic Products of the Malay Peninsula, vol. II, p. 1240.

11 There were five types of Medang mentioned. They were medang brawas, medang kalaboo, medang kuning, medang pergura, and medang putih.

12 Peluso, Rich Forests, Poor People, p. 4. Also see T. N. Harper, "The Politics of the Forest in Colonial Malaya," Modern Asian Studies 31, 1 (1997): 1-29.

13 The most popular harvesting areas were Pulau Rupat and near the Siak-Mandau juncture. Anderson, Mission to the East Coast of Sumatra in 1823, pp. 172-176, 349; Balthasar Bort, "Report of Governor Balthasar Bort on Malacca: 1678," trans. M. J. Bremner, with introduction and notes by C. O. Blagden, Journal of the Malayan Branch of the Royal Asiastic Society (JMBRS) 5, 1 (1927): 182.
} 
available near Melaka, an active industry seems to have already been in full force in eastern Sumatra that made obtaining the needed timber easier. The focus on the elite, who are assumed to have control over natural resources in their territories, is emphasized in a series of treaties signed between the VOC and Johor in 1685, 1689 and 1715, all mentioning access to timber. ${ }^{14}$

The European's preferred strategy of focusing on one person or group that controlled access to timber was enhanced after 1718, when a new leader named Raja Kecik gained power along the Siak river and created a polity that was independent of Johor. According to both Dutch and English records, this new Siak elite now supervised the harvesting, particularly for timber obtained upstream. The proximity of timber regions to their new capital of Buantan allowed Siak officials to meet the European ships to oversee the cutting and loading of the timber personally. ${ }^{15}$ This created an additional layer of authority, which masked local participation in the timber trade.

The centralization of authority continued well into the nineteenth century. The control over timber allowed the Siak elite to gain benefits from their trading partners in Melaka or Penang. One notes, for example, the efforts of a Siak sultan, Raja Muhammad Ali, to gain access to Javanese ports in the 1770s, efforts involving negotiations with the Dutch in Melaka. During that period the Siak ruler requested the right to send two ships to Java to purchase salt, but initially the VOC in Melaka refused since it would have violated Company trade restrictions. After receiving several letters from the Siak sultan, the VOC in Melaka finally agreed to grant the passes, but with prohibitive conditions, to which Raja Muhammad Ali replied by banning all Dutch trade and wood cutting in Siak. ${ }^{16}$ Because this threatened Dutch interests, the VOC acquiesced and allowed the salt trade to occur unhindered. By 1775, the issue of passes for Siak ships was a major topic in secret correspondence between Melaka and Batavia, and beginning the next year six Siak vessels were allowed direct access to rice and salt trade from Java without any compensation to the Company. The Dutch were allowed access to timber areas following such cooperation. ${ }^{17}$

While the treaties and negotiations between the Siak leaders and European officials make it appear that the elite enjoyed full control of timber access, in truth access was often determined by local leaders and indigenous groups (orang asli). In the east Sumatran littoral there were numerous groups that were known as orang asli. These groups were traditionally associated with the collection of natural resources from the forest and sea, and were usually portrayed as extremely loyal to the spiritual and economic authority of the Malay ruling elite of the region. Their loyalty

\footnotetext{
${ }^{14}$ Leonard Y. Andaya, Kingdom of Johor, 1741-1728 (Kuala Lumpur: Oxford University Press, 1975), pp. 140-145, 167-170, 324-327; J. E. Heeres, ed., Corpus Diplomaticum, Nederlando Indicum, III, (The Hague: Martinus Nijhoff, 1934), pp. 380-387, 492-497; Corpus Diplomaticum, IV, p. 442; Peluso, Rich Forests, Poor People, p. 37.

15 For a general overview of how this was done, see VOC 2630: Memorie of Gov. Rogier de Laver, f. 44; VOC 3090: Letter from M. Barselman to Gov. David Boelen (written April 29, 1763).

${ }^{16}$ The VOC conditions would have required that Siak ships pay one hundred rijksdaalders for each pass to Java. VOC 3334: Letter from Mohamat Ali to Governor and Council in Malacca (received January 3, 1770).

17 VOC 3470: Secret Letters from Malacca to Batavia for 1775, f. 339-341; VOC 3495: Letter to the King of Siak, (written August 29, 1777); VOC 3554 (2nd part): Letter to King of Siak (written April 20, 1779), Letter from Muhammad Ali, King of Siak (received June 6, 1779); VOC 3599: Letter to Raja Ismail (written March 29, 1780), Letter to King of Siak (written October 14, 1780).
} 
supposedly motivated the orang asli laborers to cut and haul the trees when requested by the elite. Access to any of the natural resources of the region could not have occurred without their cooperation. While there are numerous stories of elite participation in the timber trade, the role of indigenous groups in this trade, and their relationship to the Siak and Johor states, is often neglected in these same accounts.

Despite the general lack of anecdotal evidence about the orang asli in the premodern timber trade, certain revealing episodes do appear in various sources. These occasional descriptions cover the seventeenth, eighteenth, and nineteenth centuries. As one might guess after noting the development of the Siak polity in the eighteenth century, the ability of state structures to deal with the orang asli was enhanced during this period as the two came into closer contact. The transformation that occurred was not simply a matter of winning the loyalty of indigenous communities, but ultimately meant subjugating them. In the process, the orang asli who participated in endeavors like timber harvesting lost some part of their authority over the environment.

An early description of orang asli participation in the timber trade appears in the journal of William Dampier, an English captain who sailed around the world in the late seventeenth century and visited the Straits of Melaka in 1689. During his stay at the VOC post in Melaka, Dampier learned of a Captain Johnson who had gone to Bengkalis to purchase a sloop. The vessel needed some repairs so Johnson sailed "about 5 or 6 leagues from Bencalis Town with his Carpenter to cut a Boltsprit; there being plenty of Timber Trees fit for his purpose." They stayed at the harvesting site for three days working on a piece of wood, and on the third day the party was attacked by a "band of armed Malayans," who killed both Johnson and the carpenter. Two of the remaining four crewmen died in the repeated attacks carried out by a reported forty to fifty men in six to eight canoes. The attackers were described as "very treacherous," and having, "but little Commerce with Strangers." When the two surviving crew members returned to Bengkalis they met with the syahbandar, who expressed regret but claimed there was little he could do since, "the People that did it were wild unruly Men, not subject to Government, and that it was not in his power to suppress them."18

The harvest of the timber by the English captain and his crew probably occurred on Pulau Rupat, a common timber harvesting site, which is approximately thirty kilometers from Bengkalis. After purchasing the sloop in Bengkalis, the Johor center of authority in the region at the time, the captain went to another location where he was attacked by hostile "Malays." Since Dampier had not visited the region, he may have been unaware that the islands along the coast were inhabited by a mix of peoples, often clumped together under the identification of Malay. The presence of a people that interacted very little with outsiders, however, points toward the attackers as being orang asli, probably Orang Laut or Orang Akit. The Akit are the inhabitants of Pulau Rupat, while Orang Laut were the coastal sailors who were omnipresent in the region. While the claims of helplessness and ignorance by the Bengkalis syahbandar might well be interpreted as part of a diplomatic ploy, they nevertheless emphasize the important role these indigenous groups played in regional trade. Although they were the critical link between outside traders, the elite, and the environment, these groups in eastern Sumatra were not totally under the control of any larger polity. While the economic and political relationship of Malay states with indigenous groups has often been described as one of tribute to a ruler that supplied outside trade goods, developing this

18 William Dampier, Dampier's Voyages, vol. II (New York: E. P. Dutton, 1906), pp. 41-44. 
support was often difficult and complicated for the ruler. Orang asli may have been more autonomous in their dealings with local states than previously believed, particularly when they were in a situation that gave them some control over access to a valuable trade good like timber.

The importance of appeasing the local residents of eastern Sumatra is also indicated in a 1689 treaty between the VOC and Johor, which specifically included a provision concerning access to Siak timber. ${ }^{19}$ The sixth article of the treaty states that, "the residents of the rivers of Mandau, Tapong Kiri and elsewhere, which flow into the great Siak river, are free to sell masts and poles, sprigs, etc., for ships, and also all types of house-, timber-, and firewood to the Company."20 The autonomy of local participants in the timber trade became more apparent in another treaty signed between the VOC and Johor in 1715, which included a provision specifically dealing with timber harvesting. The fifth article states that traders from Melaka may cut "mast, timber, and fire wood" from the Siak forest, "as has been traditionally practiced." 21 Siak timber had become such an important issue that the VOC considered it necessary to insure access through the signing of formal agreements between elites, while Johor accepted its inability to control the "residents" of eastern Sumatra in such "traditional" pursuits. As long as ships were made of wood, and the region was able to supply it, timber from eastern Sumatra would remain a valuable tool in relations between local groups and foreign traders.

The importance of orang asli is further emphasized in Dutch reports of VOC ships being sent to gather timber and firewood in 1690. Dutch officials returning to Melaka from the Siak river reported that timber gathering was possible in east Sumatran swamps, but the wood was "soft" (zacht), counter to what was expected of the rainforest hardwoods found farther upstream, and unfit for the construction and maintenance of vessels.22 Despite having access to the region, the VOC had discovered that there was little they could do without the full cooperation of local groups, and their leaders, who were knowledgeable in the characteristics of certain trees and their locations.

Although these sources indicated that indigenous groups involved in the timber trade did show some autonomy in the late seventeenth century, the creation of a Siak polity in the early eighteenth century made their association with the state a more complex matter. This changing relationship is exemplified in an episode that took place in 1763. In that year VOC officials at a post on Pulau Gontong on the Siak river, fearing an attack from forces hostile to their presence, decided to construct a new and reinforced fence around their compound. To facilitate the process, the supervisor of the post, Marcelis Barselman, sent a letter to the Siak sultan, Raja Alam, requesting assistance in the cutting and hauling of timber. Soon after the request was sent, a group of the "king's folk" arrived to provide the needed services. These people were performing traditional corvée duties, which in this case involved the cutting and hauling of wood for the VOC on behalf of the Siak sultan. Although the performance of this task at the request of the ruler implies a certain amount of deference to his

\footnotetext{
19 Corpus Diplomaticum, III, pp. 492-497; Andaya, Kingdom of Johor, pp. 167-170, 326-327.

20 Corpus Diplomaticum, III, p. 495.

21 Corpus Diplomaticum, IV, p. 442. "gelijk van ouds practiseerd is."

22 Generale Missiven van Gouverneurs-Generaal en Raden aan Heren XVII der Verenigde Oostiindische

Compagniee, ed. W. Ph. Coolhaas (The Hague: Martinus Nijhoff, 1967), V, p. 409.
} 
position, there were limits to the orang asli submission. After cutting and hauling over seven hundred trees, the "king's folk" refused to work any more. Barselman thought he had solved the problem when he agreed to pay them, but they continued to refuse to provide the services for either the sultan or the VOC. ${ }^{23}$ Apparently the seven hundred trees fulfilled the obligations the orang asli thought they owed to the spiritual and political authority of the Siak ruler. Eventually, Raja Alam sent his son, Raja Muhammad Ali, to negotiate with the intransigent laborers. In a separate letter to Melaka, Raja Muhammad Ali wrote that the fence had finally been finished using a combination of the seven hundred trees and lighter nibong palms, which were easier to cut and haul. ${ }^{24}$

The 1763 construction of the palisades on Pulau Gontong suggests that the relationship between orang asli groups and the state was in transition. In 1689 indigenous groups were considered to be beyond the control of larger authorities in the region, as shown in the attack on Captain Johnson at Pulau Rupat. Following the creation of the Siak state, a centralized authority moved closer to orang asli and established the power to demand certain duties from them. Although the group involved in the construction of the palisade was most likely different from that involved in the 1689 attack, there is enough evidence to support the conclusion that the general relationship between the parties was changing. Indigenous groups still had the ability to openly oppose the wishes of an outside power, but they were being drawn into the Malay system of government. This change is emphasized in the growing presence of Siak appointed officials meeting European crews for pre-arranged timber harvests. For example, a penghulu, an official who traditionally oversaw orang asli groups, met with a VOC crew while his followers did the cutting and hauling of the trees in 1779.25

The continuing deterioration of of the indigenous groups' autonomy occurred as the Siak state grew in power. By the early nineteenth century Siak rulers were claiming that they would be able to deliver large amounts of timber through their control of orang asli cutters and haulers. This took place during a period of changing economic status for many of the groups in eastern Sumatra. While capitalistic European trading companies had been present in the Straits of Melaka for centuries, their trade activities were circumscribed, for in fact they could manage nothing more than access to Siak's trading ports. As the status and power of the companies and Siak changed, however, the English in Penang began to negotiate specific contracts for the supply of wood from Siak forests. By 1810, at least two ships had been made for the English solely from Siak timber. ${ }^{26}$

The changing status is symbolized by Said Zain, a Siak noble. Said Zain was also known as Tuanku Pangeran and was famous for his cosmopolitan charm, which

23 VOC 3090: Letter from M. Barselman to Gov. David Boelen, (written April 29, 1763); Letter from M. Barselman to Gov. David Boelen, (written May 26, 1763). For a view of corvée labor in Siak see Anderson, Mission to the East Coast of Sumatra in 1823, p. 178.

24 VOC 3090: Letter from Raja Alam to Governor and Council in Malacca, (received August 4, 1763); Letter from Raja Mahomat Ali to Gov. David Boelen and Council in Malacca, (received August 4, 1763).

25 VOC 3554 (Second Part): Letter from Muhammad Ali, King of Siak, (received June 6, 1779).

26 T. Puvanarajah, Penang's Early Relations with Sumatra, 1786-1824 (Unpublished Academic Exercise, University of Malaya in Singapore, 1960), pp. 61-62; Marsden, The History of Sumatra, p. 161. 
94 Timothy P. Barnard

allowed him entry into the offices of European officials in the Straits. ${ }^{27}$ When John Anderson visited Siak in 1823, he noted that Said Zain commanded "an extensive boatbuilding concern, and his timber yard was well filled with large trees of very fine timber." 28 The confidence of this Siak noble in his control over the orang asli is reflected in the gift of bark cloth that he presented to Anderson, and his promises that he could provide British ports with a steady supply of timber. In his encounter with Anderson, Said Zain appeared comfortable in his role as a facilitator of this trade and, even more importantly, confident in his control over the orang asli that his promises implied.

In accounts from the colonial era, one finds evidence for the continuing loss of autonomy for orang asli groups in relation to the timber trade. Beginning in the 1850s the sultan of Siak began granting rights to Singapore firms wishing to harvest timber in Siak territories. This harvesting, which came to be known as the panglong system (referring to a Hakka word for timber) became widespread in Siak as well as throughout the Riau-Lingga archipelago. Since most panglong harvesting took place on the large islands off the east coast of Sumatra, the role of the Orang Akit and Orang Laut was enhanced. Panglong company foreman used Akit knowledge of the surrounding forest to determine the best area for cutting; in return for their assistance, these indigenous groups were remunerated with Singapore dollars. A report from the 1920s also mentions that Orang Laut families, including women and children, participated in the towing of cut trees. ${ }^{29}$

Although there are only a few reports of the participation of indigenous groups in the timber trade throughout the pre-modern period in Siak, a comparison of these scattered reports with information from later centuries shows that the status of the orang asli had begun to change by the eighteenth century, earlier than many scholars have acknowledged. While the declining position of the orang asli relative to the state and capitalist companies has been described in numerous sources, such a loss of autonomy is usually considered symptomatic of the expanding twentieth century colonial state or even the independent Southeast Asian nation. Siak did not become part of the expanding Dutch colonial empire until 1858, and even then little attention was given to a region with poor soils and little to attract plantation owners or traders. Timber was still present in large quantities, but its usefulness in shipbuilding had diminished with advent of steamships. The presence of a timber harvesting industry in Siak thus allows for a glimpse at the changing role of the orang asli in a pre-modern state prior to its entry into the colonial era. ${ }^{30}$ The loss of autonomy for indigenous groups in eastern Sumatra was not initiated by Dutch colonial rule or even Chinese panglong farms. It had begun with the founding of the Siak state in the early eighteenth century. While the Dutch and English appetite for timber did provide a motive, it was the proximity of the ruling elite, and the enforcement of traditional obligations, that allowed for greater control to be exercised over the orang asli. This control was not

27 Annabel Teh Gallop, The Legacy of the Malay Letter (Warisan Warkah Melayu) (London: British Library, 1994), p. 145; Anderson, Mission to the East Coast of Sumatra in 1823, pp. 167-168.

28 Anderson, Mission to the East Coast of Sumatra in 1823, p. 176.

${ }^{29}$ G. Pastor, De Panglongs (Weltevreden: Landsdrukerij, 1927), pp. 6-10; Erwiza Erman, "Tauke, Kuli, dan Penguasa: Eksploitasi Hutan Panglong di Riau," Sejarah: Permikiran, Rekonstruksi, Persepsi 5 (1994): 20-33.

${ }^{30}$ For a discussion of similar issues, but in relation to the expansion of a commercial plantation crop, see Carl A. Trocki, Prince of Pirates: The Temenggongs and the Development of Johor and Singapore, 1784-1885 (Singapore: Singapore University Press, 1979). 
always easy to enforce, as seen in the 1763 palisade incident, but was part of an increasing subjugation of indigenous groups to the larger state as relationships changed and individuals and companies like Said Zain and Chinese panglong companies grew in power and profited.

\section{Conclusion}

The timber trade in Siak was an important industry which has often been overlooked in the studies of the region. As Knaap and Nagtegaal have pointed out in their study of the salt trade, such everyday items may not be spectacular, but they typically form the bulk of trade and "provide important clues for a better comprehension of Asian societies." 31 Like the salt trade, the trade in natural forest products, not normally mentioned in European traders' reports, played a vital role in regional commerce. The European trade companies did have a need for the timber of the region. The harvesting and exchange of timber allowed for high level connections between the rulers of Siak and the British and Dutch colonial enterprises.

Access to trade, however, was not a simple task. Without the cooperation of the orang asli much of the cutting and hauling could not be accomplished. Their knowledge of the environment and of particular species of trees gave them power in the forest. Along with their accumulated knowledge of the variety of species available, they could be expected to understand, for example, the difference between choosing Serapat or Medang trees. Such knowledge made the orang asli valuable residents of the region, but also targets of attempts to introduce some form of control over their activities. The founding of the Siak state allowed its rulers to exercise some authority over these groups at least a century before colonial rule, a situation that increasingly robbed the indigenous groups of their autonomy. Ironically, these local rulers are often portrayed as "protectors" of these indigenous groups. ${ }^{32}$ The scattered accounts of the timber trade in Siak, however, imply that it was Malay rulers who initiated changes that led to loss of dominion for the orang asli.

Although the timber trade may appear to have given Siak a prominent position within the trading community of the Melaka Straits, it also must be remembered that outside of Siak it was viewed as simply supplying a product to a centralized processor. In such terms, Siak was a marginalized region that supplied some of the many products needed in Batavia and Penang, a minor producer among many others. As van Leur pointed out in his groundbreaking essay, however, states such as Siak were vital centers of trade and commerce that were neglected in the historical records because they chiefly dealt in goods popular among Southeast Asians and not Europeans. ${ }^{33}$ The timber trade in pre-modern Siak brought slight European recognition to the region. The trade in natural products, like oil and timber today, formed one aspect of the relationship of Siak with the wider world that ultimately led to the Siak rulers' loss of

31 Gerrit Knaap and Luc Nagtegaal, "A Forgotten Trade: Salt in Southeast Asia, 1670-1813," in Emporia, Commodities, and Entrepreneurs in Asian Maritime Trade, c. 1400-1750, ed. Roderich Ptak and Dietmar Rothermund (Stuttgart: Franz Steiner Verlag, 1991), p. 127.

32 For an example of how the relationship between the orang asli and traditional stated in the Siak region is perceived, see Tenas Effendy, "Petalangan Society and Changes in Riau," Bijdragen tot de Taal-, Land-, en Volkenkunde (BKI) 153, 4 (1997): 632-633.

33 J. C. van Leur, Indonesian Trade and Society (The Hague: W. van Hoeve, 1955), p. 276. 
96 Timothy P. Barnard

authority over their own territory. A similar loss, resulting from similar dynamics, had been visited on the pre-modern local community a century before the advent of economic and political colonization. 